\title{
Selva Trágica e o subdesenvolvimento brasileiro: um diálogo estético-político entre o romance de Hernani Donato e o filme de Roberto Farias
}

\author{
Crisrober dos Santos Silva ${ }^{\mathrm{i}}$ \\ Volmir Cardoso Pereira ${ }^{\mathrm{ii}}$
}

\section{RESUMO}

Este artigo analisa comparativamente o romance Selva trágica (1959), escrito por Hernani Donato, e o filme homônimo (1964), dirigido por Roberto Farias, visando compreender o modo como as obras literária e cinematográfica tematizam o subdesenvolvimento brasileiro, a partir dos parâmetros formais do romance social e do realismo cinematográfico que caracteriza o início do Cinema Novo. Em geral, procuramos demonstrar como as obras dialogam com as questões políticas e ideológicas de seu momento histórico, a partir da especificidade de cada linguagem e campo artístico. Para tanto, embasamo-nos na crítica cultural materialista, sobretudo em Cevasco (2013), Jameson (1992) e Eagleton (1978), como também em estudiosos do período histórico abordado e em teóricos do cinema e da literatura.

Palavras-chave: Crítica cultural materialista; Selva trágica; Romance social brasileiro; Cinema Novo.

\begin{abstract}
This article comparatively analyzes the novel Selva trágica (1959), written by Hernani Donato, and the homonymous film (1964), directed by Roberto Farias, aiming to understand how literary and cinematographic works portray Brazil as an underdeveloped country, based on formal parameters of the social romance and of the cinematic realism that characterize the beginning of Cinema Novo. In general, we seek to demonstrate how the works dialogue with the political and ideological issues of their historical moment, based on the specificity of each language and artistic field. To do so, we refer to materialistic cultural criticism, more specifically to Cevasco (2013), Jameson (1992), and Eagleton (1978), as well as to scholars of the historical period covered and theorists of cinema and literature.
\end{abstract}

Keywords: Materialistic cultural criticism; Selva Trágica; Brazilian social novel; New Cinema.

\footnotetext{
${ }^{\mathrm{i}}$ Mestre em Letras pela Universidade Estadual de Mato Grosso do Sul (UEMS). Email: crisrobersantos@gmail.com

ii Doutor em Estudos Literários pela Universidade Estadual de Londrina (UEL) e professor adjunto nos cursos de Letras da Universidade Estadual de Mato Grosso do Sul (UEMS). ORCID: http://orcid.org/0000-0002-7581-1890 | volmircardosop@gmail.com
} 


\section{CONSIDERAÇÕES INICIAIS}

Neste texto, discutiremos a obra Selva Trágica (1959) de Hernani Donato e a adaptação fílmica homônima (1964), dirigida por Roberto Farias, buscando apresentar de que modo a perspectiva ideológica em torno do subdesenvolvimento brasileiro se apresenta em ambas. Para tanto, desenvolveremos um diálogo interartes entre cinema e literatura, buscando revelar confluências e tensões no processo de criação estética, tendo em vista suas implicações políticas e culturais no momento histórico em que as obras foram produzidas.

De início, convém destacar que este artigo apresenta resultados de investigação produzida em dissertação de mestrado, defendida no ano de 2020, que visou discutir como o romance Selva trágica e sua adaptação fílmica compartilham um horizonte político, cultural e intelectual que marca o fim dos anos 1950 e início dos anos 1960, para o qual a formulação do conceito de subdesenvolvimento é fulcral para a compreensão da realidade brasileira (SILVA, 2020). Em geral, expusemos que é possível observar na literatura de Hernani Donato certa continuidade com o programa estético e político do romance de 1930, tendo afinidades com a ideologia nacional-desenvolvimentista, enquanto o filme de Farias insere-se, de maneira mais direta, no contexto cultural efervescente dos primeiros anos da década de 1960, próximo das premissas do Cinema Novo.

Assim, à luz da crítica cultural materialista, vinculada aos estudos interartes, tomamos como pressuposto a perspectiva de que os produtos culturais guardam em si, tanto em forma quanto em conteúdo, as marcas dos embates travados na sociedade e na história, uma vez que "a cultura concretiza relações sócio-históricas e o trabalho da crítica é examinar os modos como a arte descreve e interpreta essas relações" (CEVASCO, 2013, p. 16). No caso da adaptação fílmica de obra literária, é fundamental também levar em conta processos intersemióticos e interculturais que desvelem possibilidades de compreensão dos objetos em diálogo, muito além de falsas questões como "fidelidade". Sobre isso, cabe destacar:

O lema deve ser 'ao cineasta o que é do cineasta, ao escritor o que é do escritor', valendo as comparações entre livro e filme mais como um esforço para tornar mais 
claras as escolhas de quem leu o texto e o assume como ponto de partida, não de chegada. (XAVIER, 2003, p. 62)

Por isso, o objetivo deste texto é observar em que medida as obras em diálogo podem fornecer uma visão rica e complexa da sociedade na qual emergiram, a partir de seus recursos estéticos próprios, embora tenham partido de uma mesma fábula (mythos). Em nossa perspectiva, as obras literárias e fílmicas guardam em suas formas de representar as estruturas ideológicas de seu momento histórico, compondo figuras que reproduzem ou tensionam os discursos que circulam na vida social. Nesse sentido, o horizonte político e ideológico do texto narrativo (verbal ou audiovisual) sempre se define pelo modo como a ação humana pode ser representada, pois:

\footnotetext{
A ideologia não é em primeiro lugar um conjunto de doutrinas; ela significa o modo como os homens vivem até o fim os seus papéis na sociedade de classes, os valores, ideias e imagens que os ligam às suas funções sociais e os impedem, assim, de conhecer verdadeiramente a sociedade no seu conjunto. (EAGLETON, 1978, p. 30)
}

Tendo em vista que as obras de arte nunca estão à frente de seu tempo, mas são sempre as que melhor sabem reconhecer o espírito de sua época, expondo-o como problema de seus próprios meios expressivos, entendemos que o romance e o filme aqui analisados permitem realizar uma boa reflexão sobre o momento histórico em que foram realizados, observando as relações indissociáveis entre estética, ideologia e política.

\section{O SUBDESENVOLVIMENTO BRASILEIRO COMO CONCEITO IDEOLÓGICO NO CONTEXTO CULTURAL E POLÍTICO DOS ANOS 1950-1960}

Toda obra literária ou cinematográfica guarda uma dimensão política a ser recuperada pela atividade crítica. Para Fredric Jameson (1992), a chave política é o horizonte absoluto de toda leitura e interpretação. Os textos carregam os conflitos de seu tempo histórico, das relações de poder convertidas em ideologia, das estruturas de sentimento que se constituem a partir das relações de produção, enfim, uma configuração social que perpassa o conteúdo e a forma das narrativas, embora nem sempre de modo consciente. 
Posto isso, passemos a analisar o contexto cultural e político das obras em questão. Cronologicamente, ambas integram o período que antecede e abarca o Golpe Civil-Militar de 1964, marcado pela euforia desenvolvimentista advinda do governo de Juscelino Kubitschek e pelo acirramento dos conflitos de classe no país, levando-se em conta também o contexto geopolítico da Guerra Fria. Pode-se dizer que o discurso nacionaldesenvolvimentista do governo JK (1955-1960) dera a tônica ideológica no período, pois se colocava como uma proposta para a superação do atraso do país, mediante a modernização das relações produtivas e a implementação de uma indústria nacional competitiva. Enquanto discurso que apelava à unidade da nação, o nacionaldesenvolvimentismo propunha também superar a dualidade entre o interior e o centro do país, o arcaico e o moderno, o campo e a cidade (BENEVIDES, 1991). Todavia, cabe lembrar que os conflitos de classe que definiam o drama político brasileiro naquele momento, situavam o governo de JK em um ambiente institucional de disputas violentas pelo poder: "o governo de Juscelino encrava-se, pois, num período extremamente crítico, entre o suicídio de Getúlio Vargas (agosto 54) e a renúncia de Jânio Quadros" (BENEVIDES, 1991, p. 10).

Desse modo, a ideologia nacional-desenvolvimentista, ancorada em investimentos públicos e industrialização dos grandes centros do país, apresentava-se sobretudo como slogan político, ao passo que os conflitos violentos e a desigualdade social seguiam marcando a realidade brasileira. Nesse sentido, o conceito de subdesenvolvimento assume o centro do debate intelectual da época, a partir de expoentes como Celso Furtado, que desenvolveu análises da economia brasileira junto aos estudos do CEPAL (Comissão Econômica para a América Latina e o Caribe).

Para Furtado, que participou ativamente dos governos de Kubitschek e Goulart, o subdesenvolvimento brasileiro era resultado das relações capitalistas mantidas em países com histórico de colonização, marcados pela exportação de matérias-primas e importação de bens industrializados, gerando endividamento constante e a dependência de capital externo. De acordo com Schwarcz e Starling:

As análises da Cepal contribuíram para embasar o Plano de Metas, mas o livro de Celso Furtado, além de apresentar instrumentos para uma nova maneira de pensar o país, fornecia aos técnicos do governo uma palavra-chave - "subdesenvolvimento" - para enquadrar os dilemas da sociedade brasileira. (SCHWARCZ \& STARLING, 2015, p. 707) 
Para que a condição de subdesenvolvimento fosse superada, segundo Furtado, era necessária a implantação de reformas que alterassem a estrutura do estado e da sociedade, o que abriu um novo campo de disputas políticas, pois tocavam em questões enraizadas no modo de vida e que se traduziam em privilégios para os setores médios e altos. Mesmo assim, as reformas de base foram encampadas pelas forças progressistas organizadas (sindicatos e movimentos sociais) e assumiram forma político-institucional em 1962, através do programa de reformas do governo João Goulart. A palavra "subdesenvolvimento" passou a fazer parte dos debates públicos e foi se incorporando ao imaginário político do período. Como recorda Schwarcz e Starling (2015, p. 708), “era preciso pôr em evidência o lugar do subdesenvolvimento para melhor enfrentá-lo".

É certo que o conceito não ficou circunscrito ao campo da política ou da economia. A possibilidade de modificar a realidade vigente e o imperativo de se expor as mazelas sociais foram incorporadas ao campo cultural, influenciando diversas produções artísticas do período. Em 1958, por exemplo, os atores do Teatro de Arena realizaram a apresentação da peça Eles não usam black tie, que colocava em cena a vida miserável do operariado brasileiro e a repressão constante ao movimento grevista. No cinema, o filme de Nelson Pereira dos Santos, Rio, 40 graus, lançado em 1955, registrava a vida nas periferias ("favelas") do Rio de Janeiro, escancarando a miséria social e o cotidiano do povo, seguindo os moldes do Neorrealismo Italiano. Sobre este filme, que marcara uma nova possibilidade de representação cinematográfica e uma nova sensibilidade estética, Motta diz:

Como propunha o neorrealismo italiano, o filme de Nelson colocava o povo nas telas. Pobres, negros, marginalizados, atores populares, sob a luz bruta e ofuscante dos trópicos, em favelas e trens suburbanos, histórias de luta e solidariedade, dramas e comédias do cotidiano carioca. Apesar das ideias comunizantes que motivaram a proibição oficial, Rio, 40 graus foi distribuído pela Columbia Pictures, que não só recuperou o adiantamento pago à produção, como o multiplicou muitas vezes. Nelson estava duplamente feliz: o filme tinha conseguido ganhar uma luta pela liberdade de expressão e arrastar multidões aos cinemas. O povo se via na tela, se reconhecia naqueles personagens, naqueles cenários, vivendo suas lutas cotidianas. A ação política encontrava sua melhor expressão nessa nova estética. (MOTTA, 2011, p. 52)

Assim, artistas e intelectuais se organizavam para produzir, nos mais diversos meios culturais, a denúncia das condições de vida da classe trabalhadora, bem como a miséria social gerada nos grandes centros urbanos do país e também nos rincões mais afastados. Esta configuração político-militante do fazer artístico marcou a atividade de 
cineastas, músicos, dramaturgos, artistas plásticos e escritores, tendo por expoente o Centro Popular de Cultura, criado em 1962 no Rio de Janeiro.

Na literatura, podemos dizer que a questão do subdesenvolvimento vinha sendo posta, de maneira mais consciente, desde os anos 1930. O romance social e regionalista do período buscava fugir ao estereótipo do exotismo, advindo do naturalismo do século XIX. A consciência do subdesenvolvimento em Graciliano Ramos, Jorge Amado, José Lins do Rego, entre outros, busca representar a miséria humana a partir de suas causas econômicas, e não mais a partir de uma visão eugenista de condenação da mestiçagem racial ou de degenerações atávicas (CANDIDO, 1989). A protoconsciência do subdesenvolvimento, na geração de 30, implicava uma denúncia da realidade e a crítica contumaz da exploração capitalista em um país de herança colonial e escravocrata.

Conforme o conceito de subdesenvolvimento ia adquirindo estofo teórico e político nas décadas seguintes, os intelectuais eram estimulados a uma postura mais combativa, focada na possibilidade revolucionária de transformação das relações de classe:

Com efeito, quanto mais o homem livre que pensa se imbui da realidade trágica do subdesenvolvimento, mais ele se imbui da aspiração revolucionária - isto é, do desejo de rejeitar o jugo econômico e político do imperialismo e de promover em cada país a modificação das estruturas internas, que alimentam a situação de subdesenvolvimento. (CANDIDO, 1989, p. 149)

Para Candido, é em Guimarães Rosa que se estabelece plenamente a consciência crítica do subdesenvolvimento, pois a questão regional é suplantada pela dialética entre o singular e o universal, a aldeia e o mundo. O super-regionalismo roseano, com seu experimentalismo na linguagem,

[...] corresponde à consciência dilacerada do subdesenvolvimento e opera uma explosão do tipo de naturalismo, que se baseia na referência a uma visão empírica do mundo; naturalismo que foi a tendência estética peculiar a uma época onde triunfava a mentalidade burguesa e correspondia à consolidação das nossas literaturas. (CANDIDO, 2006, p. 95)

A obra de Guimarães Rosa, junto com a de muitos outros escritores latinoamericanos do período, propõe uma nova abordagem crítica da realidade por meio da linguagem, abandonando o pitoresco e a suposta objetividade do relato documental. No entanto, grande parte das obras do período não alcançou esse patamar, pois a 
representação do regional ainda permaneceu presa aos limites do exotismo naturalista, embora também apresentassem o tema da miséria e da violência social.

Vejamos, portanto, como o romance Selva trágica e o filme homônimo se inserem nesse contexto de tomada de consciência a respeito do subdesenvolvimento brasileiro, e como foram capazes de representar, com a riqueza de seus próprios meios expressivos, as contradições, angústias e utopias do seu momento histórico.

\section{A UTOPIA NACIONAL-DESENVOLVIMENTISTA E A DENÚNCIA SOCIAL NO ROMANCE DE HERNANI DONATO}

O romance Selva Trágica (1959) retrata a situação de trabalhadores de ervais, no interior do então estado do Mato Grosso, na região fronteiriça com o Paraguai durante as primeiras décadas do século XX. Essa obra de Hernani Donato dá continuidade à temática social de suas obras anteriores, como Chão Bruto (1957), em que a luta pela terra entre posseiros e grileiros no interior de São Paulo, no início do século XX, está no centro da narrativa. As narrativas de Donato, em linhas gerais, guardam traços naturalistas e ancoram-se no relato documental, mas também incorporam as estratégias narrativas do romance social da geração dos anos 1930. Pode-se dizer que Selva trágica surge, em fins dos anos 1950, como mais um romance regionalista, embora fosse visto pelo mercado editorial como uma novidade, pois trazia certo ingrediente "exótico" ao retratar a fronteira Mato Grosso-Paraguai, região do centro-oeste brasileiro pouco explorada nas obras literárias de destaque.

Apesar de o enredo do romance se desenvolver em torno dos anos 1930, momento em que o governo de Getúlio Vargas abolira o monopólio de exploração dos ervais pela Companhia Matte Larangeira, é possível afirmar que a realidade social registrada no livro era ainda verificável nos anos 1950. Na época em que Hernani Donato coletava informações para a produção da obra, ainda havia uma parcela significativa da população que estava submetida às mesmas condições degradantes de trabalho nos ervais, como atesta o autor:

Mas quando me embrenhei nos ervais de Mato Grosso, isso no final da década de 1950, havia ainda cerca de 5 mil homens e mulheres trabalhando em condições extremamente precárias, sem descanso, durante 14 horas diárias, das 3 da manhã às 5 
da tarde, na colheita e no transporte da erva - entre a "mina" e o acampamento o mate tinha de ser levado, pelo meio da selva, em fardos de 150, 200 quilos, amarrados às costas dos trabalhadores. (DONATO, 2005)

A busca pelo registro literário desta realidade degradante encontra similaridade com as narrativas do Romance de 30, em autores como Graciliano Ramos, Rachel de Queiroz, José Lins do Rego e Jorge Amado. Assim, podemos dizer que Donato se inscreve nesta tradição realista que atravessa o século XIX e as primeiras décadas do século XX, junto ao experimentalismo modernista e às novas técnicas narrativas que são assimiladas pelos escritores. Nesse sentido, é importante pontuar linhas de continuidade, mas também diferenças entre o momento histórico e cultural de Donato e seus antecessores.

Sobre o romance social latino-americano dos anos 1930, Candido pontua que houve ali um ponto de inflexão na literatura naturalista e regionalista: a representação pitoresca do mundo rural e do sertão, que seria típica a um "país novo" e exótico como o Brasil, cede lugar a um "regionalismo problemático", no qual vai emergindo a consciência política do subdesenvolvimento:

\footnotetext{
Na fase de pré-consciência do subdesenvolvimento, ali pelos anos de 1930 e 1940, tivemos o regionalismo problemático, que se chamou de "romance social", "indigenismo", "romance do Nordeste", segundo os países, e, sem ser exclusivamente regional, o é em boa parte. Ele nos interessa mais, por ter sido um precursor da consciência de subdesenvolvimento. (CANDIDO, 1989, p. 160)
}

No caso brasileiro, o Romance de 30 representava essa mudança de orientação frente ao naturalismo do fim do século XIX, pois em Jorge Amado, José Lins do Rego, Graciliano Ramos, o drama do homem sertanejo já não aparece como destinação trágica ou atavismo biológico, mas antes como produto da ostensiva exploração econômica, geradora da miséria física e simbólica. Ainda segundo Candido, essa protoconsciência do subdesenvolvimento, inscrita no romance social de 1930, parecia antever os debates sobre o tema que surgiriam, de modo sistemático, após a Segunda Grande Guerra: "Não é falso dizer que, sob este aspecto, o romance adquiriu uma força desmistificadora que precede a tomada de consciência dos economistas e políticos" (CANDIDO, 1989, p. 142).

Em linhas gerais, podemos dizer que Selva Trágica seria continuador ou talvez um epígono do romance social de 1930, especialmente próximo dos romances proletários de Jorge Amado, influenciados pelo realismo soviético. Todavia, é preciso dar um passo 
adiante e situá-lo na complexidade de seu momento histórico, para além do campo literário e sua tradição. Nessa perspectiva, cabe perguntar: se os anos 1950 expressavam o entusiasmo nacional-desenvolvimentista, quais situações ultrapassadas e limitadoras o país precisava abandonar? Trazer à tona a exposição crua de um Brasil arcaico e violento, valendo-se do estereótipo da fronteira como espaço sem controle da lei e do Estado, não era uma forma de gerar a imagem invertida desse desenvolvimentismo alardeado? $\mathrm{O}$ contraste era muito mais evidente do que antes, portanto. Passemos a analisar o romance um pouco mais de perto.

Em Selva Trágica narra-se a trajetória de Pablito, um changa- $y^{1}$ capturado pela Companhia Matte Larangeira e obrigado a trabalhar arduamente nos ervais para reparar o "prejuízo" gerado à empresa. Sua mulher, Flora, é motivo de disputa entre os homens do rancho Bonanza, local em que ocorre a maior parte da ação. Nesse entremeio, a exploração cruel dos trabalhadores, a violência e a degradação física e moral são os temas que vão se desdobrando em cenas rápidas e encadeadas. Com capítulos curtos e foco no avanço encadeado da ação dramática, a narrativa não dá muita abertura à descrição mais minuciosa do espaço ou à inquirição psicológica, valorizando a força expressiva de cenas também curtas, organizadas em blocos narrativos. Embora haja uma continuidade na ação, carregada de tensão dramática, tais blocos abrem-se para narrativas paralelas e apresentam alguns saltos temporais (analepses e prolepses), o que aponta a incorporação de procedimentos estéticos modernistas, para além dos traços naturalistas evidentes.

O tempo diegético, embora não tenha ancoragem precisa na historiografia, inscreve-se no contexto da década de 1930, momento em que o monopólio de exploração da erva-mate pela Companhia Matte Larangeira é questionado e revogado pelo governo de Getúlio Vargas.

O espaço diegético, por sua vez, ancora-se no mapa geográfico da exploração da erva-mate no sul de Mato Grosso, na região de Ponta Porã, fronteira com o Paraguai. Nesse tempo e lugar, a narrativa ampara-se no tom documental, criando personagens-tipo e estruturando a ação dramática a partir dos registros históricos e testemunhais do que teria sido a superexploração dos trabalhadores dos ervais a partir do monopólio da Companhia. Fundada em 1872, a empresa passara ao controle de acionistas argentinos e detinha até meados dos anos 1930 o domínio total da região por regime de concessão, exercendo papel de polícia das terras devolutas, além de cobrar impostos pela exploração 
da erva e autorizar outras atividades comerciais em seu território, como se fosse um “estado dentro do estado" (SILVA, 2011, p. 121).

Não é nosso objetivo analisar em profundidade o modo como a narrativa literária emula ou recupera o registro historiográfico em seu plano de conteúdo, mas apenas destacar algo fundamental para a compreensão político-ideológica do momento histórico em que o romance foi escrito: em Selva Trágica, o monopólio empresarial e a persistência do trabalho escravo, disfarçado de trabalho assalariado, expressariam um modelo atrasado que deveria ser superado pela instauração da concorrência, da livre-iniciativa e do trabalho assalariado, bandeiras do nacional-desenvolvimentismo da década de 1950 .

Assim, segundo o próprio Hernani Donato, a obra faz o "relato da vida e do trabalho sob o ângulo dos que a suportaram mais rudemente: mineiros, changa-ys, marginais, pequenos funcionários" (DONATO, 1976, p. 7, grifo nosso). Cenas expressivas e marcantes do trabalho degradante nos ervais são recorrentes na narrativa, apontando uma preocupação política de denúncia social, evidenciada no discurso figurativo. Como exemplo, podemos citar esta cena, em que se descreve o trabalho dos mineiros carregando o raído, fardo de erva que podia pesar entre 60 e 150 quilos:

\footnotetext{
Meio dia. Avançam pelo tapê, pernas duras, passadas curtas... o raído passa uma alça forte ao redor da cabeça do mineiro. Ela solda a carga ao homem e evita que a espinha dorsal se parta. Ao fim de cem passos, quando o raído "assenta", a alça começa a latejar, como se batesse para entrar nas parede do crânio... o homem, de cabeça presa ao raído e o corpo entesado, não enxerga onde pousa os pés... se pisa fora da trilha e escorrega ou tropeça morrerá debaixo do fardo. Se nesse tombo a espinha fratura, agonizará dolorosamente durante horas. Caminha bestializado... nem palavras, nem cantos, nem chamados. (DONATO, 1976, p. 21)
}

Outras cenas, como o estupro e morte de uma menina prostituída nos ervais (DONATO, 1976, p. 165), os castigos com chicote de cauda de lagarto (teyu-ruguay), impingidos aos trabalhadores que não cumpriam suas obrigações ou se revoltavam (DONATO, 1976, p. 109), entre outros, ilustram reiteradamente o tema da degradação física e moral no ambiente dos ervais. Talvez a cena mais impactante seja a que apresenta o trabalho insalubre do uru no barbaquá2. O Uru é apresentado ironicamente como o "rei do rancho", pois seu trabalho exige grande perícia e dele depende a qualidade da ervamate a ser consumida. A ironia reside no fato de ele ter várias regalias que outros 
trabalhadores não possuem, ao mesmo tempo em que seu trabalho é o mais degradante de todos, pois em pouco tempo terá comprometido completamente sua saúde física:

\begin{abstract}
Faria isso durante seis anos, ou oito, ou dez se muito saudável. E pronto! Um uru jamais chega à idade madura. Vive oito ou dez anos que são oito, dez safras, ao redor do barbaquá, virando e revirando a erva, recebendo no peito o calor do fogo e nas costas a friagem da noite. Oito ou dez anos o uru vive e é rei. Depois morre morrendo... Quando o patrão lhe põe nas mãos a forquilha e lhe dá o piso do barbaquá, diz que ele é o senhor. Então começa a respirar fumo e resina, a ser defumado em suor e fumaça. Primeiro a gordura, depois as carnes, a saúde, escorrem pelo corpo, dia e noite feito suor. Nenhum pelo lhe fica grudado no corpo, nem saliva na boca, nem dentes nas gengivas, nem lágrimas nos olhos. Vai sendo cozido dia a dia; os intestinos acabam secos e mortos, envenenando o corpo; o estômago ácido, os pulmões cavernados, as veias saltadas, os olhos afundados. (DONATO, 1976, p. 34)
\end{abstract}

O uru é o símbolo máximo da exploração, da brutalidade dos ervais, pois traz no seu corpo arruinado o registro mais claro da degradação a que os homens são submetidos neste sistema: "quando alguém bebe da erva, o que bebe de fato é o sangue do uru, o suor do uru" (DONATO, 1976, p. 93).

Nesse sentido, o heroísmo trágico de Pablito, que é morto lutando contra os representantes da Companhia, tem certo caráter de redenção destas vidas degradadas, pois ele representa aquele que não se entrega ao seu destino de maneira resignada.

Dessa forma, os changa-ys e mineiros, tipificados positivamente no heroísmo de Pablito, aguardam o fim do monopólio e a modernização das relações produtivas nos ervais da fronteira leste de Mato Grosso. Em nossa leitura, esse desejo de modernização corresponde à ideologia desenvolvimentista, tão comum nos tempos finais dos anos 1950, momento em que o romance é escrito. Nesse sentido, é a personagem do político Luisão a que repercute este anseio modernizante, observando também as dificuldades para que a lei federal pudesse ser aplicada naqueles rincões:

O governo está longe, tem a vista fraca demais para enxergar o que se passa no meio do mato. E a erva está no meio do mato. Não nos jardins do palácio do governo. Agora vamos lutar contra outro tipo de poder; o dinheiro, a política, o suborno, a malícia. (DONATO, 1976, p. 198)

Selva trágica, em 1959, conversa com questões latentes em seu tempo, como a dualidade entre campo e cidade, centro e periferia/fronteira, a modernização e o atraso, o arcaico e o moderno, o estrangeiro e o nacional. Se a obra serve como denúncia, também 
serve a um ideal desenvolvimentista, descrevendo de forma crua o "atraso" e o subdesenvolvimento, tendo por contraponto o ideal nacional-desenvolvimentista. Na voz de Luisão e na revolta dos changa-ys, organizados politicamente junto dos mineiros, reside a tomada de consciência sobre o status quo e a necessidade de superá-lo. A "selva trágica" é, portanto, a imagem invertida que destaca a necessidade do desenvolvimento capitalista brasileiro, projetado ideologicamente nos anos 1950 e representada ao final do romance.

\section{A SOLUÇÃo TRÁGICA E O PESSIMISMO POLÍTICO NO FILME DE ROBERTO FARIAS}

Lançado em agosto de 1964, portanto alguns meses após o Golpe Civil-Militar no Brasil, o filme Selva trágica, dirigido por Roberto Farias, expunha nas telas um Brasil violento e "atrasado", adaptando um romance da década de 1950 que tratava de um rincão pouco conhecido no Brasil: a fronteira Brasil-Paraguai, no antigo Mato Grosso. Como veremos a seguir, apesar de a adaptação fílmica ser fiel ao enredo literário, pelo menos em seu núcleo dramático principal, há mudanças significativas em seu conteúdo ideológico, na medida em que a euforia nacional-desenvolvimentista cede lugar a um horizonte trágico e pessimista, gerado pela repressão estatal e a "modernização conservadora", atrelada aos interesses do imperialismo norte-americano.

De início, convém ressaltar que a relação entre cinema e literatura é bem evidenciada em fins dos anos 1950 e durante os anos 1960, período que marca a ascensão das ideias do Cinema Novo na produção cinematográfica brasileira, após a falência emblemática dos estúdios Vera Cruz. De certa forma, a representação social dos filmes do Cinema Novo dialogava com o realismo/regionalismo dos romancistas de 1930, tanto nas adaptações quanto na relação poético-formal. Este diálogo com o realismo e o modernismo literário, sem dúvida, correspondia à assimilação do Neorrealismo Italiano e da Nouvelle Vague francesa pelos cineastas brasileiros. Em 1963 era lançado Vidas Secas, dirigido por Nelson Pereira dos Santos, um dos filmes mais representativos e premiados do Cinema Novo, inspirado no clássico de Graciliano Ramos, publicado em 1938. Depois vieram filmes como Menino de engenho (1965), de Walter Lima Junior, $A$ hora e a vez de Augusto Matraga (1965), de Roberto Santos, São Bernardo (1972), de 
Leon Hirszman. Em geral, podemos dizer que a temática do Romance de 30, ou mesmo a da obra posterior de Guimarães Rosa, estava alinhada com preocupações estéticopolíticas dos cineastas, pois evidenciavam a questão do subdesenvolvimento, da exploração violenta e da miséria social que assolavam a maior parte da população brasileira, especialmente aqueles que viviam distantes dos grandes centros urbanos.

Todavia, importa destacar que o Cinema Novo dialogava não só com a literatura modernista e o regionalismo dos anos 1930, mas também com outras manifestações culturais que lhe eram contemporâneas, como o teatro, a música e as posições políticas dos artistas e estudantes que compunham o Centro Popular de Cultura. O cinema, nesse sentido, era uma expressão artística integrada com processos políticos que pretendiam gerar transformações sociais a partir da produção cultural, afirmada também enquanto resistência anti-imperialista. É nesse cenário que Glauber Rocha escreveria o manifesto Uma estética da fome, publicado em 1965, reivindicando um cinema eminentemente político e de resistência. Nesse sentido, a fome e a miséria não seriam apenas temas para o conteúdo fílmico, mas também aspectos da própria forma e seus meios expressivos. Logo, a precariedade da câmera que filma, a falta de recursos para gravar, a não adesão aos grandes estúdios e ao star system, são colocados como condições expressivas para um autêntico cinema político, em um país subdesenvolvido. Cabe lembrar Paulo Emilio Salles Gomes (1996, p. 85), quando afirmou que "o subdesenvolvimento do cinema não é uma etapa, um estágio, mas um estado”. Assim, no manifesto, Glauber Rocha postulou:

[...] o Cinema Novo se marginaliza da indústria porque o compromisso do Cinema Industrial é com a mentira e com a exploração. A integração econômica e industrial do Cinema Novo depende da liberdade da América Latina. Para esta liberdade, o Cinema Novo empenha-se, em nome de si próprio, de seus mais próximos e dispersos integrantes, dos mais burros aos mais talentosos, dos mais fracos aos mais fortes. (ROCHA, 2004, p. 64)

$\mathrm{Na}$ perspectiva do cineasta baiano, o fazer cinemanovista não devia ser compreendido apenas em sua dimensão estética de vanguarda, mas como um compromisso político, na medida em que mesmo os cineastas não tão "talentosos" poderiam ser importantes para a luta emancipatória da América Latina. É nesse sentido que, no início dos anos 1960, o Cinema Novo participou de um intenso debate sobre os rumos do país, sobre as possibilidades de reflexão a respeito de questões sociais como, por exemplo, as discussões sobre as reformas de base pretendidas por João Goulart. Era, 
portanto, um contexto fértil para a produção de filmes que retratassem a condição 'terceiro-mundista” em tom de denúncia social. A narrativa de Selva trágica foi, portanto, levada ao cinema por Roberto Farias a partir desta perspectiva estético-política definida pelo Cinema Novo.

O filme de Roberto Farias, nesse sentido, pode ser compreendido como obra cinemanovista, mesmo o autor não tendo participado diretamente do grupo que incluía Glauber Rocha, Nelson Pereira dos Santos, Cacá Diegues, Ruy Guerra, Paulo César Saraceni, Leon Hirszman, entre outros. Selva trágica, ao ter sido produzido na transição entre os anseios populares do governo de João Goulart e o início da Ditadura, bloqueando a via democrática, já não reverbera a utopia nacional-desenvolvimentista presente no romance, pois a ideia de progresso social e modernidade conduzida pelo Estado é substituída, naquele momento, pela luta contra os aparelhos estatais repressivos e ideológicos, atrelados ao interesse imperialista. Assim:

\begin{abstract}
O cinema, ao se politizar, assumiu a equação da pobreza e da desigualdade social tal como expressa na noção de subdesenvolvimento que, formulada no plano da economia, assumia o princípio de que não se tratava apenas de uma nova descrição da distância entre pobres e ricos, centro e periferia, mas da elucidação de uma engrenagem a ser combatida. (XAVIER, 1993, p. 5)
\end{abstract}

Deste modo, as escolhas dos autores, linguagem, forma, espaço, montagem, visavam revelar ao público as situações que evidenciavam o subdesenvolvimento e o sistema econômico que o produz.

Por outro lado, excetuando-se Selva Trágica, os outros filmes de Roberto Farias não podem ser associados diretamente à proposta estético-política do Cinema Novo. Tais filmes tinham uma preocupação comercial muito evidente, o que colocava Roberto Farias próximo dos gêneros hollywoodianos, especialmente o cinema policial, como em Cidade Ameaçada (1960) e Assalto ao Trem Pagador (1962). Ademais, convém lembrar que nos anos 1950 o diretor havia realizado algumas chanchadas como Rico ri à toa (1957).

Para Glauber Rocha, Roberto Farias tinha todas as qualidades de um cineasta que dominava as técnicas e métodos da profissão, sendo o "mais completo artesão brasileiro" (ROCHA, 2003, p. 137). Ou seja, o elogio guarda também uma depreciação, na medida em que o cineasta carioca seria um artesão das imagens, mas não um artista, um "autor de cinema" com estilo próprio bem definido. Para Glauber, Roberto estaria preso às 
convenções do cinema norte-americano, portanto, aquém da proposta crítica do Cinema Novo. No entanto, Selva trágica parecia indicar um "novo" Roberto Farias:

\footnotetext{
Quando despedir as influências americanas, libertar-se da câmera, do efeito mecânico e preocupar-se mais com os personagens, com o homem e seu meio social, contribuirá progressivamente para um novo cinema. Selva Trágica anuncia um Roberto Farias evoluído. (ROCHA, 2003, p. 137)
}

Elogiado pelos cinemanovistas, Selva trágica, ainda que aparentasse estar distanciado das tensões políticas do momento, pois fazia referência a um momento histórico já superado (o monopólio da Matte Larangeira e a escravidão nos ervais, no início do século XX), sem conectá-lo com as lutas do presente, as condições de produção do filme, falam muito sobre a importância e a relevância da história, para se tornar conhecida aos brasileiros, como bem destaca o diretor:

\footnotetext{
O filme se passa em nosso tempo. O monopólio foi extinto. Mas as condições de vida do ervateiro eram as mesmas quando filmei Selva Trágica. As condições de trabalho continuam as mesmas. Os fardos da erva-mate, chamados 'raidos', pesam no mínimo 150 quilos. (FARIAS, 1970)
}

Como destaca o diretor carioca, o filme expunha a atualidade do drama vivido pela população rural na fronteira Brasil-Paraguai, que mesmo com o fim da Companhia Matte Larangeira e com o desenvolvimentismo posterior aos anos 1950, seguia vivendo em regime de intensa exploração no meio rural. Todavia, o caso singular do trabalhador na fronteira Brasil-Paraguai podia ser visto como mais um exemplo da exploração da classe trabalhadora no Brasil, guardando correspondência inclusive com a fração que se encontrava nas grandes cidades. A construção de Brasília nos anos 1950, por exemplo, ocorrera mediante a intensa exploração dos "candangos", trabalhadores que vinham do nordeste com a promessa da construção de uma nova vida, mas que foram expostos a jornadas excessivas de trabalho, com baixa remuneração e sob vigilância policial. Sem perspectivas emancipatórias, o operariado de Brasília se estabeleceu nas favelas e cortiços que depois viriam a constituir as cidades-satélites (RIBEIRO, 2008). O urbano e o rural, o arcaico e o moderno, revelavam a mesma face cruel da exploração capitalista. As condições precárias de trabalho dos ervateiros, portanto, ecoavam nos canteiros de obra de Brasília, revelando as contradições e ilusões do nacional-desenvolvimentismo. 
Cabe ainda destacar que a produção do filme também revela aspectos ideológicos importantes sobre o fazer cinematográfico em meados dos anos 1960, especialmente a dificuldade de os intelectuais, artistas e cineastas se conectarem com a vida do povo e representar ou interpretar seus anseios. Fazer do cinema arte de denúncia, capaz de ser porta-voz dos oprimidos, esbarrava na própria diferença de classe entre o cineasta (classe média) e o trabalhador brutalizado dos ervais, como podemos ver neste depoimento do diretor:

\begin{abstract}
A produção custou o dobro do que prevíamos, em consequência das dificuldades de trabalho que enfrentamos. Chovia frequentemente, impedindo as filmagens. Passamos o natal de 1963, o Ano Nôvo e o Carnaval de 64 lá. O problema da comunicação com os figurantes e a mão-de-obra era difícil, porque eles falam uma mistura de guarani e espanhol...ao verificar que todos lá andavam armados, com arma de fogo ou facão, também nos armamos. Por exemplo: eu andava com um calibre 38 no cinto, o Riva com uma Winchester. A gente local não pratica violência normalmente, mas é gente primitiva. Por uma disputa insignificante um deles quis matar o David Havt. (FARIAS, 2012)
\end{abstract}

O medo da violência e da brutalidade dos oprimidos, tidos como incivilizados, desvela uma fantasia de classe média, reproduzida na fala de Farias, especialmente quando usa a expressão "gente primitiva". Ao mesmo tempo, ir em busca deste encontro com a realidade, apesar dos limites ideológicos de quem a mira/registra, fez com que Selva trágica pudesse dialogar diretamente com as aspirações do movimento cinemanovista, expressando o desejo de transformação da sociedade que guiou artistas e intelectuais, mesmo diante de um golpe de estado que instaurou um regime ditatorial em meados dos anos 1960 no Brasil.

Filmando no município de Ponta Porã, o diretor buscou reconstruir o espaço diegético do romance de Donato, incorporando os moradores locais para atuação no filme e assimilando o contexto cultural (música, festas, costumes) na composição das cenas. Tais premissas remetiam às obras anteriores do Cinema Novo, muito influenciadas pelo Neorrealismo Italiano. O filme condensa e agrupa as histórias do livro, excluindo alguns núcleos dramáticos e focalizando especialmente a relação amorosa entre Flora e Pablito e o triângulo estabelecido com Isaque, o capataz do rancho. Assim como no romance de Donato, o filme se esmera em registrar com detalhes as formas de exploração dos mineiros, com ênfase documental e traço naturalista. Todavia, o filme acrescenta vários elementos típicos do cinema comercial, como os tiroteios e embates ostensivos, além do 
duelo final entre Casimiro e Pablito, emulando em boa medida os clichês do western e dos filmes de aventura.

Pode-se dizer que há uma incorporação dos elementos do cinema de gênero articulada com a preocupação realista que dá o tom do filme. Na trilha sonora, por exemplo, há a incorporação da música tradicional da fronteira (polca, chamamé), mas que em vários momentos remete aos temas épicos dos faroestes norte-americanos. A música extradiegética é marcada pelas composições de Luiz Bonfá, prestigiado violonista brasileiro, executadas por Luis Bordon, muitas vezes com um coro feminino de vozes.

A fotografia do filme é de José Rosa, que também trabalhara no Filme Vidas Secas (1963). Carregada de tons escuros, ela explora em diversos momentos a contraluz, ressaltando apenas as silhuetas humanas em um espaço sombrio e insalubre. A ausência de luz projetada sobre as personagens quando estão executando suas tarefas, ou a iluminação parcial em penumbras, reforçam a degradação das personagens no ambiente em que vivem/trabalham, condicionando o caráter ao meio, em uma visada naturalista.

Figura 1: Flora, ao centro, em meio aos homens do rancho

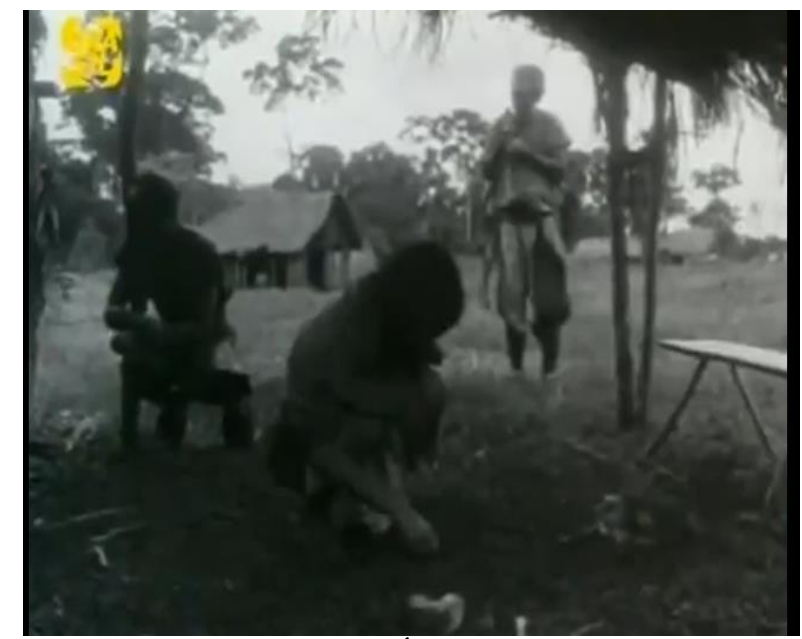

Fonte: SELVA TRÁGICA, 2019, 21:37. 


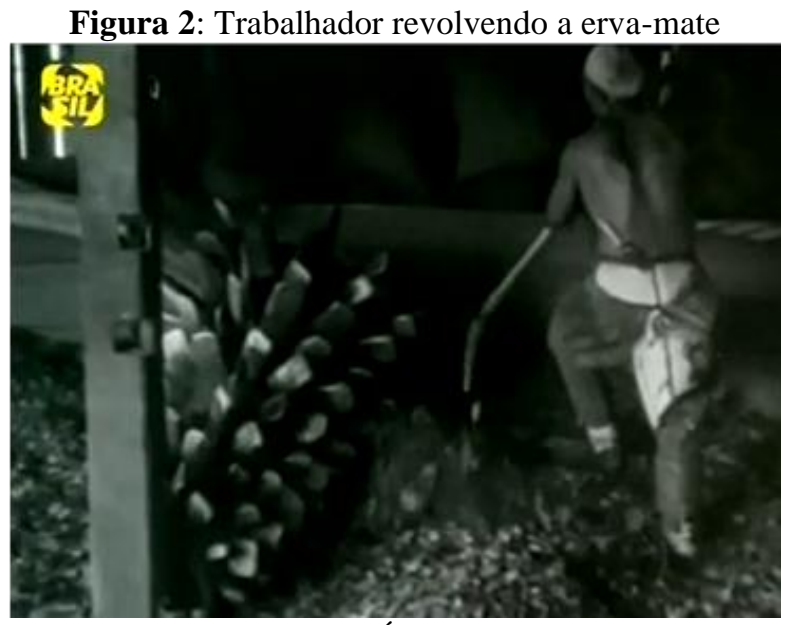

Fonte: SELVA TRÁGICA, 2019, 18:39.

Como podemos observar, na Figura 01, a contraluz apaga as personagens, ao mesmo tempo em que a câmera está na altura de Flora, acocorada, reforçando a perspectiva de sujeição da mulher frente aos homens do rancho. Aliás, em muitas cenas do filme, as mulheres são sempre posicionadas abaixo das figuras masculinas, ou enquadradas em plongée, o que acentua o tema da inferioridade e objetificação da mulher nos ervais. Na figura 02, o trabalhador cancheando a erva é mostrado em um plano longo, no qual apenas parte de seu corpo é iluminada. Sem dar a conhecer o rosto da personagem, ela se revela apenas como mais uma peça do processo de produção da erva, em seu trabalho de Sísifo. A câmera percorre o espaço, mostrando a identidade entre meio e personagem, por vezes desacelerando a tensão narrativa, conforme os pressupostos do Neorrealismo Italiano e da imagem-fato, pois no plano "[...] toda a superfície da tela deve apresentar uma densidade concreta igual" (BAZIN, 1991, p. 253).

Em outra direção, Selva trágica incorpora também elementos do western, tanto na estrutura dramática do triângulo amoroso que opõe herói (Pablito) e vilão (Isaque) na disputa pela mulher (Flora), como nas provas que revelam a bravura do herói (tiroteios, lutas corporais, fugas). Tomemos por exemplo a cena em que os comitiveiros armam uma emboscada para os ladrões de erva (changa-ys), logo no início do filme. A câmera subjetiva identifica-se com a visão dos atiradores atocaiados, enquanto os changa-ys se aproximam pelo interior da mata. Iniciam-se os disparos e a sequência do tiroteio segue os clichês do faroeste, com planos curtos, sons abundantes de tiros, oponentes se movimentando rapidamente e fazendo acrobacias exageradas, trazendo a lógica do espetáculo para o filme. 
Figura 3: Pablito e Flora, acossados durante a emboscada

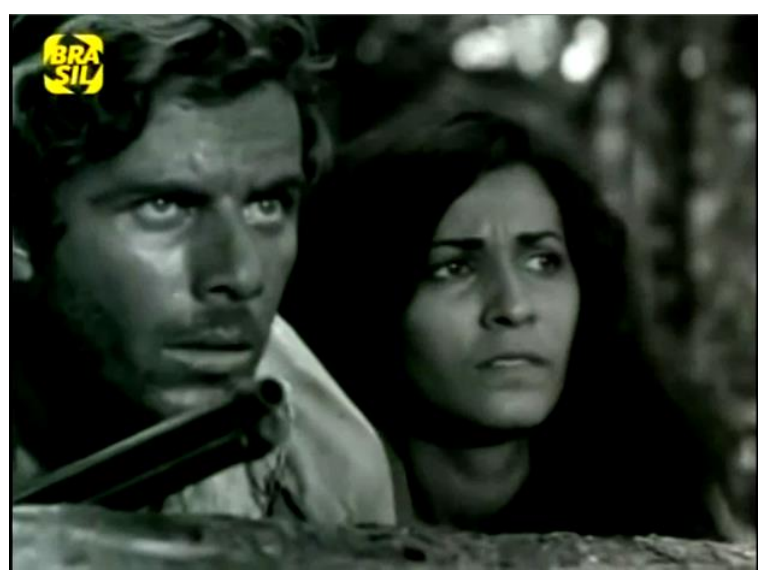

Fonte: (SELVA TRÁGICA, 2019, 14:16.

Figura 4: Protagonistas em situação de embate

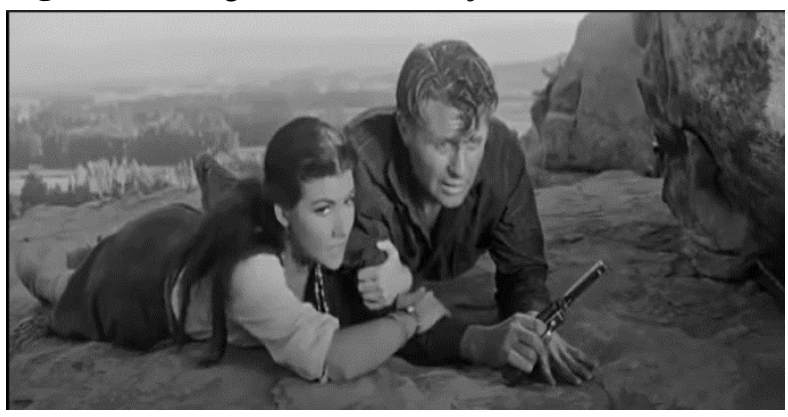

Fonte: O REVÓLVER SILENCIOSO, 2020, 39:31.

A semelhança entre a composição de cenas acima, ilustra muito bem a adesão de Roberto Santos ao estereótipo do western, cristalizado no fotograma do filme O Revólver silencioso (1957), de William F. Claxton. Uma apropriação que certamente visava a uma estratégia comercial, na medida em que o público brasileiro consumia muitos filmes do gênero nos cinemas brasileiros da época.

Apesar desta adesão a elementos do cinema de gênero/comercial, convém ressaltar que o seu realismo formal e crítico o aproxima bastante do Cinema Novo, conforme já postulamos. Nesse sentido, convém dizer ainda umas palavras sobre a sequência mais emblemática do filme: os mineiros levantando e carregando o raído pela mata. Em uma cena dentro da sequência, um dos trabalhadores se prepara para levantar o fardo de erva-mate. Um corte seco leva a um plano com a câmera enquadrada na altura do solo. O capataz, a meio corpo, no primeiro plano e o mineiro ao fundo, ajoelhado. Quando o mineiro coloca as duas mãos ao chão, para se firmar e erguer o peso, inicia-se 
um tema de violão em tom menor, com notas semibreves, que acompanharão lentamente o processo, até que o mineiro se levante para carregar o fardo. A câmera se mantém no chão, colocando o espectador ao nível do mineiro, para que o acompanhe até ficar próximo à bota do comitiveiro, que lhe é oferecida como apoio para se levantar.

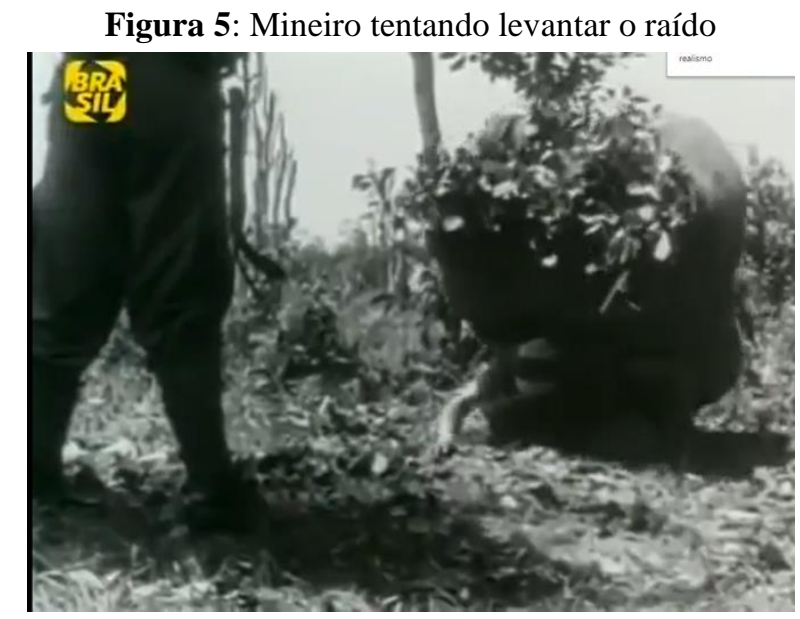

Fonte: SELVA TRÁGICA, 2019, 27:29.

Desde o momento em que põe as mãos como apoio no chão, passam-se sessenta segundos até que o trabalhador se levante com o raído, tempo suficiente para que se possa ver com detalhes seu corpo estremecer sob o peso, suas pernas e mãos fincadas no solo, como as patas de um animal quadrúpede. Em seguida, a câmera-na-mão acompanha a fila dos trabalhadores bestializados, carregando os raídos pela mata, levando o espectador a sentir os passos lentos e penosos de sua marcha através dos movimentos bruscos do próprio equipamento. $\mathrm{O}$ virtuosismo de José Rosa, que conduz a câmera, atrelado às escolhas formais de Roberto Farias, criam uma potência visual que impressiona o espectador, sensibilizando-o diante do "calvário" vivido pelos trabalhadores.

Por último, convém discutir o elemento trágico que encerra a obra cinematográfica. Nele, implicações de ordem político-ideológica se revelam. Após Pablito, Flora e outros mineiros fugirem do rancho, buscando chegar ao Paraguai, Casimiro, o valente comitiveiro, sai em seu encalço com seus homens. Após ficar sozinho e encurralado, depois de intensa perseguição, Pablito aceita sua morte iminente, mas esbraveja aos inimigos que ainda lhe restam possibilidades de causar mais algumas baixas para o outro lado. Propõe então um acordo a Casimiro, pedindo a ele que não contasse a 
Flora sobre sua morte em troca de sua rendição. Com o acordo firmado, Pablito se suicida, recusando-se a entregar-se a seus inimigos. Casimiro manifesta respeito pelo valor e coragem de seu oponente morto, a quem considera um "irmão". Nesse desfecho, o elemento trágico se manifesta na medida em que o herói é incapaz de modificar seu destino ou o curso das coisas, podendo apenas afirmar sua coragem e honra no embate contra forças que nunca poderá vencer. Conforme Lesky:

\begin{abstract}
A verdadeira tragédia se origina da tensão entre as incontroláveis forças obscuras a que o homem está abandonado, e a vontade deste para se lhes opor, lutando. Essa luta é em geral sem esperança, afundando, mesmo, o herói cada vez mais nas malhas do sofrimento, e muitas vezes até ao naufrágio total. Todavia, combater o destino até o fim é o imperativo da existência humana que não se rende. (LESKY, 1996, p. 165)
\end{abstract}

Tal como nas tragédias gregas, a narrativa fílmica explora de modo catártico a derrocada do herói, com o qual o espectador se identifica. O filme se encerra, com os comitiveiros e Flora retornando ao rancho, todos obrigados a cumprir o seu fado. A estrutura da sociedade em que vivem cria as amarras em um ciclo de opressão e exploração instransponível e inevitável. A revolta individual de Pablito não gerou nenhuma possibilidade de organização coletiva capaz de enfrentar o poderio econômico da Companhia. A utopia de transformação política não encontra lugar aí.

\title{
CONSIDERAÇÕES FINAIS
}

Em linhas gerais, podemos dizer que o filme deflagra um pessimismo com as possibilidades de transformação política, pois a condição do subdesenvolvimento se mostra como algo completamente incorporado pelos sujeitos explorados, incapazes de se organizarem coletivamente para a revolta. Evidenciam-se aqui divergências ideológicas entre romance e filme, na medida em que os changa-ys apresentados no livro avançam a luta contra o monopólio da Matte Larangeira, valendo-se inclusive da organização partidária para isso. No livro de Donato, os changa-ys exercem um papel político importante, participando de reuniões com lideranças e acompanhando o andamento da luta pela livre exploração da erva-mate. No filme, a questão política dos mineiros contra o monopólio da Companhia é apagada. A luta que se estabelece no filme é contra as próprias condições de vida compreendidas apenas pela percepção imediata, sob o ponto 
de vista das personagens. Não se atinge um maior grau de consciência sobre a estrutura econômica de dominação e sobre os agentes sociais responsáveis por ela. Podemos dizer que filmes do Neorrealismo Italiano como Terra Tremma (dirigido por Luchino Visconti, em 1952) e do Cinema Novo como Barravento (Glauber Rocha, 1962), deixam evidentes a luta de classe e a luta contra o sistema, o que de certa forma foi sublimado em Selva Trágica, dando espaço ao drama passional e ao dispositivo trágico, gerador de catarse emocional.

Todavia, o pessimismo político que define o filme parece responder de maneira mais aguda às contradições do momento histórico em que foi produzido, na medida em que a ideologia nacional-desenvolvimentista entra em crise, junto com as demandas populares por representação diante do Estado e o confronto direto (guerrilha) se mostra pouco viável. O romance de Donato, por sua vez, ainda responde às expectativas desenvolvimentistas da década de 1950, na medida em que reverbera a crença em uma modernidade capitalista que pudesse estabelecer a laissez-faire, a concorrência e o fim do trabalho escravo nas regiões mais "atrasadas" do país. As obras, em sua complexidade estética, repercutem os anseios políticos e contradições do tempo histórico em que foram produzidas.

\section{Referências}

BAZIN, André. "O Realismo cinematográfico e a escola italiana da Libertação". In: $O$ cinema: ensaios. Tradução: Eloisa de Araújo Ribeiro. São Paulo: Brasiliense, 1991, p.233-257.

BENEVIDES, Maria Vitória. "O governo Kubitschek: A esperança como fator de desenvolvimento". In: GOMES, Angela de Castro (org.). O Brasil de JK. Rio de Janeiro: Ed. Da Fundação Getúlio Vargas/CPDOC, 1991.

CEVASCO, Maria Elisa. O diferencial da crítica materialista. In: Ideias, Campinas, v. 4, n. 2, p. 15-30, 2013.

CANDIDO, Antonio. "Literatura e subdesenvolvimento". In: A educação pela noite \& outros ensaios. São Paulo: Ática, 1989, p 140-162.

Literatura e sociedade. Rio de Janeiro: Ouro sobre azul, 2006. 
DONATO, Hernani. Um contador de muitas histórias. SESC. 2005. Disponível em https://www.sescsp.org.br/online/artigo/compartilhar/3398_UM+CONTADOR+DE+M UITAS+HISTORIAS. Acesso em: 15 ago. 2019.

Selva Trágica: a gesta ervateira no sulestematogrossense. São Paulo: Autores Reunidos, 1959.

Selva Trágica. São Paulo: Edibolso, 1976.

EAGLETON, Terry. Marxismo e crítica literária. Tradução: Antonio Souza Ribeiro. Porto: Edições Afrontamento, 1978.

FARIAS, Roberto. Roberto Farias em ritmo de artindústria. In: Revista Filme Cultura. Rio de Janeiro. Instituto Nacional do Cinema. P 7-12 N 15. Julho/Agosto 1970.

GOMES, Paulo Emílio Salles. Cinema: trajetória no subdesenvolvimento. 2. ed. Rio de Janeiro: Paz e Terra. 1996.

JAMESON, Fredric. $O$ inconsciente político. A narrativa como ato socialmente simbólico. Trad. Valter Léllis Siqueira. São Paulo: Ática, 1992.

LESKY, Albin. A Tragédia Grega. Tradução de J. Guinsburg, Geraldo Gerson de Souza e Alberto Guzik. São Paulo: Editora Perspectiva, 1996.

MOTTA, Nelson. A primavera do Dragão. A juventude de Glauber Rocha. Rio de Janeiro: Objetiva, 2011.

RIBEIRO, Gustavo Lins. O Capital da Esperança. A experiência dos trabalhadores na construção de Brasília. Brasília: Editora da Universidade de Brasília, 2008.

ROCHA, Glauber. Eztetyka da fome 65. In: Revolução do Cinema Novo. São Paulo: Cosac Naify, 2004, p. 63-67. . Revisão crítica do cinema brasileiro. São Paulo. Cosac Naify, 2003.

SCHWARCZ, Lilia Moritz; STARLING, Heloisa Murgel. Brasil: uma biografia: Com novo pós-escrito. Editora Companhia das Letras, 2015.

SELVA TRÁGICA. Direção: Roberto Farias. Rio de Janeiro: Líder Cinematográfica, 1964, 101min., son., preto e branco. Idioma: português. Disponível em: https://youtu.be/G_4NUUOAcmg. Acesso em: 15 jun. 2019.

SILVA, Walter Guedes da. "Controle E domínio Territorial No Sul Do Estado De Mato Grosso: Uma análise Da atuação Da 'Cia Matte Laranjeira'no período de 1883 a 1937'. Agrária (São Paulo. Online). São Paulo, vol. 1, nº 15, p 102-125, 2011. Disponível em https://www.revistas.usp.br/agraria/article/view/79014 . Acesso em: 22 mai, 2020. 
XAVIER, Ismail. Alegorias do Subdesenvolvimento: cinema novo, tropicalismo, cinema marginal. São Paulo: ed. Brasiliense, 1993.

Recebido em: 05/06/2021

Aceito em: 21/07/2021

\footnotetext{
${ }^{1}$ Nome de origem guarani utilizado para definir os "ladrões de erva", trabalhadores clandestinos que plantavam e comercializavam a erva-mate ilegalmente no território de concessão da Companhia Matte Larangeira.

${ }^{2}$ Forno em alta temperatura, onde se sapecava a erva-mate, visando secar suas folhas, preparando-a para o consumo e exportação.
} 